UDC 81.11’255.2:62

\title{
Наталія Глінка
}

кандидат філологічних наук, доцент

доцент кафедри теорії, практики та перекладу англійської мови

Національний технічний університет України

«Київський політехнічний інститут імені Ігоря Сікорського»

Київ, Україна

ORCID ID 0000-0001-7249-3615

nvglinka@ukr.net

\section{Оксана Лисиця}

магістрантка

Національний технічний університет України

«Київський політехнічний інститут імені Ігоря Сікорського»

Київ, Україна

\section{ОСОБЛИВОСТІ ВЖИВАННЯ ЛІНГВО-СТИЛІСТИЧНИХ ЗАСОБІВ У ТЕКСТАХ ЗБІРКИ ДЖЕЙМСА ДЖОЙСА «ДУБЛІНЦІ»}

\begin{abstract}
Анотація. Стаття присвячена аналізу особливостей вживання лексико-стилістичних засобів у художніх текстах англійської літератури, зокрема представлених в оповіданнях збірки Джеймса Джойса «Дублінці». Головною метою статті є висвітлення основних лексико-стилістичних засобів, застосованих автором, та аналіз їхнього прагматичного ефекту. Здійснено аналіз лексикостилістичних засобів та синтактико-стилістичних прийомів, у результаті якого встановлено, що ці засоби широко застосовуються автором у текстах збірки «Дублінці» для створення певного прагматичного ефекту: надають мові емоційного та експресивного забарвлення, підкреслюють та уточнюють образи, акцентують увагу читача на важливий змістових деталях. Зазначено, що застосування різних стилістичних засобів не $\epsilon$ рівномірним, що пояснюється їх особливостями вираження понятійної сфери. Проаналізувавши частотність уживання таких засобів у текстах збірки «Дублінці» було відмічено активне вживання метафори, епітету, гіперболи, персоніфікації, а також капіталізації та риторичних питань у різнобічному описі предметів, людей, життєвих ситуацій. Наголошено, що особливе місце посідає вживання метафори як підсилювального елементу та певного стилістичного наголосу в досліджуваних текстах збірки, що пояснюється бажанням автора перенести власне розуміння різних ситуацій та досягнути естетичного враження. Серед проаналізованих у текстах мовних одиниць метафори складають третину, що вказує на можливість її визначення як стильової домінанти в ідіостилі Джеймса Джойса. Дослідження ролі стилістичних засобів у створенні образності автором художнього тексту $є$ перспективним напрямком у сучасній лінгвістиці. Зокрема багата мова текстів Джеймса Джойса дає можливість засобами стилістики дослідити глибинний образний світ творів письменника, осягнути його мовний потенціал та прагматичний ефект.
\end{abstract}

Ключові слова: лексико-стилістичні засоби; метафора; епітет; гіпербола; персоніфікація; синтактико-стилістичні прийоми.

\section{1. ВСТУП}

Дослідженням питання стилістики сучасної англійської мови займаються провідні лінгвісти-германісти, зокрема Якубович, Дорохів, Груць, Нільсон, Джером, Брік, які у своїх наукових працях акцентують увагу на загальних особливостях та функціях англійської лексики та стилістики. Базуючись на фундаментальних здобутках у галузі лінгвостилістики, вважаємо за доцільне розглянути особливості залучення лексичних та стилістичних засобів у художніх текстах, зокрема в оповіданнях збірки Джеймса Джойса «Дублінці». Актуальність даного дослідження полягає у потребі ретельного вивчення лексико-стилістичних засобів вираження, власне через які реалізується семантика тих чи інших лексем, у текстах видатного ірландського письменника Джеймса Джойса, чиї твори у сьогоденні англомовного простору є надзвичайно популярними. 
Мета статті - висвітлення основних лексико-стилістичних засобів, застосованих Джейсом Джойсом, та аналіз їхнього прагматичного ефекту.

\section{2. МЕТОДИ}

Для вирішення поставлених завдань була задіяна комплексна методика лінгвістичного аналізу: метод прагмалінгвістичного і контекстуального аналізу - для розшифрування авторського задуму; описово-аналітичний метод - для висвітлення результатів дослідження та підбиття підсумків. У дослідженні використовуються загальнонаукові теоретичні та емпіричні методи - синтез, аналіз, узагальнення, а також контекстуальний і ситуативний аналіз.

\section{3. РЕЗУЛЬТАТИ Й ОБГОВОРЕННЯ}

Мова художніх текстів Джеймса Джойса є взірцем модерністського експерименту, що реалізується у пошуках як нових словоформ, так і через оновлення традиційної поетичної мови. У результаті аналізу текстів збірки «Дублінці» виявлено розлоге застосування автором різноманітних лексико-стилістичних засобів та синтактико-стилістичних прийомів, зокрема метафори, порівняння, епітетів, персоніфікації, ономатопеї, риторичних запитань, гіперболи, паралельних конструкцій тощо. Таким чином, можемо говорити про стилістично насичену мову текстів збірки. Для розуміння особливостей використання вище зазначених засобів наведемо презентативні приклади лінгво-стилістичних засобів та проаналізуємо авторські прагматичні мотиви їх застосування.

Найчастатнішим засобом у текстах збірки «Дублінці» $\epsilon$ метафора - троп, що представляє перенесення назви 3 одних предметів, явищ, дій, ознак на інші на основі подібності між ними (Арнольд, 2002, с. 79). Наприклад: I felt that his little beady black eyes were examining me but I would not satisfy him by looking up from my plate (Joyce, 2017, c. 6). 3a допомогою метафори автор надає читачеві опис одного з персонажів оповідання. Вираз набуває особливого художнього значення, представляє при цьому високу понятійну сферу та дає змогу читачеві чітко уявити зображену в творі дійсність.

Подібна прагматична функція й метафори у наступному фрагменті: As I did so I met the gaze of a pair of bottle-green eyes peering at me from under a twitching forehead (Joyce, 2017, p. 20). Варто наголосити, що метафора несе особливе значення та позитивно впливає на уяву читача, надаючи при цьому можливість уявити зовнішність персонажа.

They were walking quickly, the young woman taking quick short steps, while Corley kept beside her with his long stride (Joyce, 2017, с. 48). Цей фрагмент показує метафоричне пояснення рухів та дій дійових осіб, вона деталізує манеру ходити, хоча в той самий час ми можемо перенести цей опис на особливості характеру героїв оповідання. Таким чином, у читача складається повна картина як зовнішніх, так i особистісних характеристик персонажів.

He was a shabby stooped little drunkard with a white face and a white moustache and white eyebrows, pencilled above his little eyes, which were pink-veined and raw; and all day long he sat in the bailiff's room, waiting to be put on a job (Joyce, 2017, с. 50). Цього разу метафора також спрямована на опис зовнішності і підкреслює повноту вираження та характеристики персонажа. The decisive expression of her great florid face satisfied her and she thought of some mothers she knew who could not get their daughters off their hands! (Joyce, 2017, с. 53) - ще одна метафора спрямована на опис зовнішності людини. На допомогу метафорі у реченні також використане окличне речення, яке слугує більшим мотиватором до уявлення та подиву одного із героїв твору, і активно впливає на емоції читача. Таким чином, у читача може скластися особливе, та навіть можна сказати, адекватне розуміння ролі коштовності.

Отже, авторська метафора у тексті доповнює зміст, стає невід'ємним компонентом когнітивної сфери читача.

Другим по частотності вживання серед лексико-стилістичних засобів у текстах збірки «Дублінці» $\epsilon$ епітет (слово чи словосполучення, завдяки особливій функції в тексті, 
допомагає слову набути нового значення або смислового відтінку, підкреслює характерну рису, визначальну якість певного предмету або явища, збагачує мову новим емоційним сенсом, додає тексту певної мальовничості, насиченості (Арнольд, 2002, с. 102)). Характерна манера письменника та сила його художнього твору надають епітетам особливого значення (Виноградов, 2013). Виходячи 3 цього читачеві додаються окремі пояснення та збагачується його уявлення щодо подій в тексті. Джойс використовує епітети наступним чином: You are a very generous person, she said (Joyce, 2017, с. 191) - за допомогою епітетів автор надає опис манері голосу одного із персонажів збірки «Дублінці». I like that idea very much but wouldn't a comfortable spring bed do them as well as a coffin? (Joyce, 2017, c. 176). Ці епітети теж спрямовані на опис характерних речей. Саме епітети несуть особливе додаткове пояснення та впливають на понятійну та образну сферу читача. Читач не лише отримує певну додаткову інформацію, але й занурюється у художній світ твору i проймається його особливостями.

He had a beautiful death, God be praised (Joyce, 2017, с. 10). Використаний у цьому реченні епітет спрямований на опис смерті одного із героїв твору, проте вжитий він у дещо незвичному контексті.

The youngster and he were great friends. The old chap taught him a great deal, mind you; and they say he had a great wish for him (Joyce, 2017, с. 71). Епітети у вище наведеному фрагменті використані в позитивному контекстів, передаючи читачеві особливість внутрішнього світу персонажа, його піднесений настрій.

But now, after the kindling again of so many memories, the first touch of her body, musical and strange and perfumed, sent through him a keen pang of lust (Joyce, 2017, с. 189). У цьому реченні ми також спостерігаємо використання епітетів, які створюють особливе емоційнопонятійне значення та впливають на формування думки читача щодо подій в оповіданні.

У нашому дослідженні також визначено роль застосування гіперболи у текстах «Дублінців». У текстах письменника ця стилістична фігура явного і навмисного перебільшення для посилення виразності і підкреслення сказаної думки (Арнольд, 2002, c. 81) вживається таким чином: They were not much more than acquaintances as yet but Jimmy found great pleasure in the society of one who had seen so much of the world and was reputed to own some of the biggest hotels in France! (Joyce, 2017, с. 34) - крізь призму цієї цитати ми бачимо як автор використовує гіперболу та додає особливого змісту звучанню окремого речення.

У той самий час понятійна сфера використання окремо взятої гіперболи в поєднанні 3 окличним реченням дозволяє говорити нам про емоції однісї з дійових осіб. This was the first of many meetings; they met always in the evening and chose the most quiet quarters for their walks together (Joyce, 2017, c. 91). Mr. O'Madden Burke said it was the most scandalous exhibition he had ever witnessed! (Joyce, 2017, c. 125) - знову ж таки, гіпербола та окличне речення впливають на увагу читача та надають йому додаткову інформацію. Аналізуючи вище наведену цитату, ми розуміємо ставлення автора до одного з персонажів та можемо говорити навіть про певну іронічність у тексті.

She believed steadily in the Sacred Heart as the most generally useful of all Catholic devotions and approved of the sacraments (Joyce, 2017, с. 135). Використання гіперболи у наведеному прикладі несе читачеві додаткову інформацію та впливає на емоційно-чуттєву сферу. Таким чином, автор акцентує увагу читача та дає йому більше розуміння ситуації.

Працюючи над вивченням особливостей мови Джеймса Джойса у збірці «Дублінці» ми також зустріли декілька яскравих прикладів застосування персоніфікації. Власне, сам термін «персоніфікація» означає надання предметам чи явищам природи людських якостей; вид метафори, що сприяє поетичному олюдненню довколишнього світу. Наприклад: A shadow passed over his face as he remembered her sullen opposition to his marriage (Joyce, 2017, c. 163) автор персоніфікує значення тіні, яка у контексті оповідання додає особливого емоційного звучання рядкам твору.

У текстах оповідань збірки «Дублінці» одним 3 головних образів, навколо якого 
будується сюжет і якому автор надає особливого значення є гроші. I mean to marry money (Joyce, 2017, с. 67). У наведеному фрагменті «гроші» вжито у переносному значенні. A keen east wind hit them, blowing from the mouth of the river (Joyce, 2017, с. 113). У цій цитаті представлено дві персоніфікації, що надає реченню особливого літературного звучання та цікавого змісту в цілому.

Таким чином, бачимо, що автор застосовує персоніфікацію для підкреслення важливих моментів життя героїв. Саме за допомогою персоніфікації читач може зрозуміти та проаналізувати ключові образи текстів збірки «Дублінці».

Також серед стилістичних засобів вираження у текстах Джойса зустрічається приклади застосування капіталізації. Мотиви їх використання переплітаються 3 функцією виокремлення та підкреслення ряду ситуацій.

I must give you a copy of UNDER THE FIG TREE (Joyce, 2017, с. 214) - автор вдається до капіталізації для конкретизації певного місця, яке є важливим елементом розвитку подій. GOD! (Joyce, 2017, с. 219) - цього разу капіталізація свідчить про відчай однієї із героїнь твору та своєрідне благальне звернення до Бога.

Одже, можемо свідчити, що Джойс завдяки капіталізації акцентує увагу читача на важливих змістових деталях твору.

Доволі часто в текстах «Дублінців» зустрічається такий ситактико-стилістичний пройом як риторичне запитання, що представляє особливий емоційний стан персонажа та змушує читача замислитися і самому надати відповідь на запитання. Наприклад: Go where? (Јоусе, 2017, с. 165). У цьому прикладі риторичне запитання виявляє емоційне розчарування персонажа. За допомогою цього запитання автор передає критичність та певну безвихідь ситуації. But where? (Јоусе, 2017, с. 165) - у контексті риторичного запитання прихований подив одного із героїв твору. Таким чином передається своєрідне розгубленість щодо подальших вчинків та дій. And all for what? (Joyce, 2017, с. 170) - у наведеному запитанні висловлений подив та навіть розчарування у критичній ситуації.

Також варто зауважити часте використання ономатопеї, яка додає емоційного забарвлення у представленні автором дій та звуків.

Яскравими прикладами використання ономатопеї є: The peal of laughter which followed Gabriel's imitation of the incident was interrupted by a resounding knock at the hall door (Joyce, 2017 , с. 183) - ономатопея передана називанням звуку, який раптово перериває дії персонажа, що створює певну емоційну напругу. Подібний засіб, спрямований на детальний опис подій та створення особливого емоційного забарвлення, використано у наступному прикладі: Не was tired of knocking about, of pulling the devil by the tail, of shifts and intrigues (Joyce, 2017, c. 47).

В результаті аналізу було відібрано 300 лексико-стилістичних засобів та синтактикостилістичних, з яких метафор - 90; епітетів - 80; гіпербол - 45; персоніфікацій - 33; капіталізацій -7 ; риторичних запитань -45 .

Вважаємо за доцільне порівняти частотність використання лінгвостилістичних засобів у збірці «Дублінці» та відобразити результати в діаграмі (рис. 1).

Таким чином, можемо свідчити про активне використання автором лексикостилістичних та синтактико-стилістичних засобів у текстах збірки «Дублінці» та стверджувати, що вони мають особливий прагматичний ефект. 


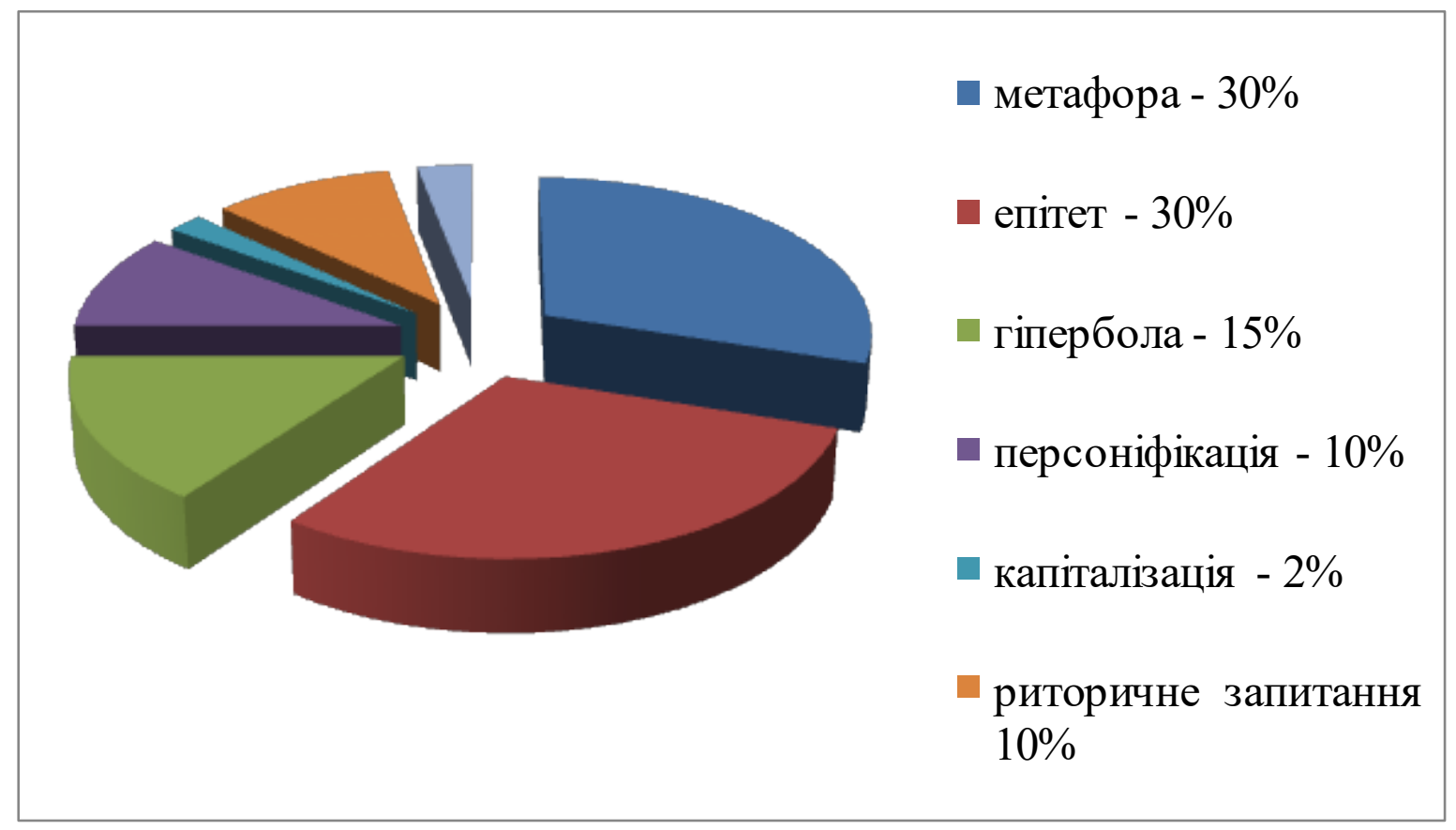

Рис. 1. Відсоткові показники використання лексико-стилістичних та синтактикостилістичних засобів у збіриі «Дубліниіі»

\section{4. ВИСНОВКИ І НАПРЯМИ ПОДАЛЬШИХ ДОСЛІДЖЕНЬ}

У результаті аналізу лексико-стилістичних засобів та синтактико-стилістичних прийомів можемо зауважити, що вони широко застосовуються автором у текстах збірки «Дублінці» для створення певного прагматичного ефекту: надають мові емоційного та експресивного забарвлення, підкреслюють та уточнюють образи, акцентують увагу читача на важливий змістових деталях.

Застосування різних стилістичних засобів не $є$ рівномірним, що пояснюється їх особливостями вираження понятійної сфери. Проаналізувавши частотність уживання таких засобів у текстах збірки «Дублінці» було помічено активне вживання метафори, епітету, гіперболи, персоніфікації, а також капіталізації та риторичних питань у різнобічному описі предметів, людей, життєвих ситуацій. Особливе місце посідає вживання метафори як підсилювального елементу та певного стилістичного наголосу у текстах збірки, що свідчить про бажання автора перенести власне розуміння різних ситуацій та досягнути естетичного враження. Серед проаналізованих у текстах мовних одиниць метафори складають третину, що вказує на можливість їі визначення як стильової домінанти в ідіостилі Джойса.

Дослідження ролі стилістичних засобів у створенні образності автором художнього тексту $є$ перспективним напрямком у сучасній лінгвістиці. Зокрема багата мова текстів Джойса дає можливість науковцям засобами стилістики дослідити глибинний образний світ творів письменника, осягнути його мовний потенціал та прагматичний ефект.

Перспективним напрямом подальшого дослідження $є$ вивчення авторських лексикостилістичних засобів та синтактико-стилістичних прийомів у інших текстах Джойса.

\section{СПИСОК ЛІТЕРАТУРИ}

Арнольд, И.В. (2002). Стилистика. Современный английский язык. М: Флинта,Наука. Виноградов, В. В. (2013). Про задачи стилистики: сборник статей. Высшая школа. Joyce, J. (2017). Dubliners. London: Press House.

\section{REFERENCES}

Arnold, I.V. (2002). Stylistyka. Sovremennyj angliiskij jazyk. M.: Flinta, Nauka. [in Russian] Vynogradov, V. V. (2013). Pro zadachi stylistyky: sbornik statej. M.: Vyshhaja shkola. [in Russian] 
Joyce, J. (2017). Dubliners. London: Press House.

Nataliia Glinka, Oksana Lysytsa. The peculiarity of linguostylistic means in the stories "Dubliners" by James Joyce. The article deals with the analysis of the peculiarities of the use of vocabulary and stylistic means in the literary texts of English literature, in particular presented in the stories Dublines by James Joyce. The main purpose of the article is to highlight the main vocabulary and stylistic tools used by the author and to analyze their pragmatic effect. The analysis of vocabulary and syntactic techniques has been carried out, which shows that these tools are widely used by the author in the texts of Dublines to create a pragmatic effect: giving the language emotional and expressive coloring, emphasizing and refining the readings, accentuating on important content details. It is noted that the use of different stylistic means is not uniform, which is explained by their peculiarities of expression of the conceptual sphere. Analyzing the frequency of such funds in the texts of the collection Dublines, we noted the active use of metaphor, epithet, hyperbole, personification, as well as capitalization and rhetorical questions in a comprehensive description of subjects, people, life situations. It is emphasized that the use of metaphor as a reinforcing element and a certain stylistic emphasis in the studied texts of the collection is of particular importance, which is explained by the author's desire to transfer his own understanding of different situations and to achieve an aesthetic impression. The study of artistic language involves the allocation of a set of labeled elements in the text of a poetic work and the study of those relationships that are established by the linguistic units relevant to identifying characteristics of the work. Such a language analysis is conducted by allocating lexical groups of different volumes (semantic field, lexico-semantic group), which are characteristic of this work in terms of linguistic and extra-linguistic factors. Stylistic analysis is not only broadens the theoretical horizons of a language learner but it also teaches the latter the skills of competent reading, on one hand, and proprieties of situational language usage, on the other. The stories Dublines are rich in various lexical-stylistic means, which have a positive effect on the verbal content of the work. Moreover, their use is appropriate for conducting descriptions, explanations, refinements, etc.

Keywords: lexical-stylistic means; metaphor; epithet; hyperbola; personification; syntactic-stylistic techniques. 